\title{
QUANTUM LEARNING DENGAN TEKNIK MIND MAP UNTUK MENINGKATKAN HASIL BELAJAR PADA MATA KULIAH HISTOLOGI-EMBRIOLOGI
}

\author{
Oleh
}

\section{Eko Sri Wahyuni ${ }^{1}$}

\begin{abstract}
Abstrak Penelitian ini bertujuan untuk merancang, mengimplementasikan serta mengetahui peningkatan hasil belajar melalui quantum learning dengan teknik mind map. Penelitian tindakan kelas ini dilakukan pada mahasiswa semester VI Program Studi Pendidikan Biologi FKIP Universitas Tanjungpura Pontianak. Penelitian ini terdiri dari 3 siklus, masing-masing siklus terdiri dari 1 kali pertemuan, tahapan PTK yang dilakukan yaitu: perencanaan, pelaksanaan atau tindakan, observasi dan refleksi. Hasil penelitian menunjukkan terjadi peningkatan hasil belajar (kognitif, afektif dan psikomotor) siklus I, II, III sebesar 22\%, 81,25\%, 96,87\%, sedangkan pada ranah afektif rata-rata pada siklus I, II, III sebesar $67,14 \%$, $73,56 \%, 76,25 \%$, sedangkan pada ranah psikomotor rata-rata siklus I, II, III adalah 63,69\%, 75,71\%, 78,83\%.
\end{abstract}

Kata Kunci : quantum learning, mind map, hasil belajar.

\begin{abstract}
The aim of this research to design, to implement as well as to find out the extent to which the quantum learning with mind map technique could improve the students' learning achievement. This classroom action research was conducted to the sixth semester students of Biology Education Study Program of Teacher Training and Education Faculty of Pontianak Tanjungpura University. This research consisted of 3 cycles, while the procedure of classroom action research included: planning, acting, observing, and reflecting. The result of research showed the improvement of learning achievement. In cognitive domain, the proportion of successfully passing was $22 \%, 81.25 \%, 96.87 \%$ in cycle I, II, III. In affective domain, the mean value was $67.14 \%, 73.56 \%, 76.25$ in cycle I, II, III. In psychomotor domain, the mean value was $63.69 \%, 75.71 \%, 78.83$ in cycle I, II, III.
\end{abstract}

Keywords: quantum learning, mind map, the learning achievement

${ }^{1}$ Eko Sri Wahyuni : adalah dosen Program studi Pendidikan Biologi FKIP Untan 


\section{Pendahuluan}

Permasalahan pendidikan yang dialami bangsa Indonesia saat ini adalah rendahnya mutu pendidikan. Menurut hasil survey pada salah satu lembaga internasional, perkembangan pendidikan di Indonesia masih belum memuaskan. Hal ini tercermin dari hasil TIMSS (Trends International In Mathematics and Science Study) yang menunjukkan bahwa kemampuan siswa Indonesia dalam bidang IPA berada pada urutan ke-38 dari 40 negara dengan skor 421 pada tahun 1999-2003. Sedangkan hasil survey TIMSS untuk tahun 2007 menunjukkan bahwa Indonesia berada pada urutan 35 dari 49 negara peserta dengan skor 427 (Purwadi, 2003). Skor ini masih tergolong low benchmark jika dibandingkan dengan skor sebelumnya. Prestasi ini nampak statis dan tidak mengalami peningkatan yang signifikan. Program Studi Pendidikan Biologi FKIP Universitas Tanjungpura Pontianak merupakan salah satu bagian dari LPTK yang membentuk calon guru Biologi yang ketika lulus dari perguruan tinggi akan terjun sebagai tenaga pendidik dan pengajar di sekolah masing-masing. Mahasiswa dibekali oleh perguruan tinggi agar memiliki kompetensi pedagogik, kompetensi kepribadian, kompetensi sosial, dan kompetensi profesional (Sagala, 2011). Berdasarkan hasil observasi langsung pada mahasiswa semester VI Program Studi Pendidikan Biologi FKIP Universitas Tanjungpura Pontianak sebelum melaksanakan penelitian ditinjau dari sudut pandang dosen dan mahasiswa, dosen masih cenderung melaksanakan pembelajaran dengan ceramah sehingga pembelajaran berlangsung satu arah saja karena masih bersifat teacher centered. Hal ini menyebabkan tidak teraktifkannya potensi dan kemampuan mahasiswa dengan maksimal, mahasiswa hanya sebagai pendengar karena pembelajaran berlangsung satu arah, akibatnya mahasiswa menjadi cenderung pasif dan dalam kegiatan pembelajaran di kelas. Media yang digunakan hanya power point yang dibuat oleh dosen.

Jika dilihat dari sudut pandang mahasiswa, mereka cenderung pasif, lebih dari 75\% mahasiswa terlihat hanya datang, duduk, dengar, diam, dan kurang bersemangat dalam mengikuti kegiatan pembelajaran. Fenomena lain yang terlihat adalah beberapa mahasiswa mengantuk, bahkan ada yang mengobrol dengan teman disebelahnya Tidak semua mahasiswa membawa sumber belajar, biasanya mereka hanya mengandalkan catatan atau hand out yang diberikan oleh dosen. Hal ini berpengaruh pada hasil belajar mahasiswa yang masih rendah. Mahasiswa juga terbiasa duduk dalam kelas yang klasikal, jarang sekali mahasiswa belajar dalam kelompok dan berdiskusi, seandainyapun mereka belajar dalam kelompok, biasanya hanya dalam kelompok yang homogen bukan kelompok yang ditata sedemikian rupa agar 
anggota kelompoknya benar-benar heterogen baik, etnis, agama, maupun kemampuannya.

Hal ini diduga menjadi penyebab mahasiswa kurang terbiasa bekerjasama dalam kelompok dan cenderung bersifat individualis. Selain itu, berdasarkan pengalaman empiris, pembuatan catatan semua mahasiswa masih berupa tulisan yang bersifat linier dan tidak ada gambar atau simbolsimbol.

Berdasarkan pengamatan pada kegiatan pra siklus menggunakan lembar observasi afektif, capaian indikator untuk masing-masing indikator afektif (teliti/cermat, disiplin, dan kerjasama) masih tergolong rendah. Begitu juga pada pengamatan menggunakan lembar observasi psikomotor, nilai ratarata capaian tiap indikator (mengamati, bertanya, membuat mind map, mengkomunikasikan, dan menyimpulkan) hanya sebesar 2,66\%. Pada aspek kognitif, nilai pra siklus dilihat dari tes sebelumnya dengan rata-rata kelas 57,68 dengan persentase kelulusan 56,25\%. Data hasil belajar tahun sebelumnya menunjukkan rata-rata nilai UAS masih di bawah nilai 60 .

Quantum learning menawarkan ide baru tentang penciptaan lingkungan belajar yang lebih baik serta yang menjanjikan bagi pelajar dan mendukung mereka dalam proses pembelajaran agar terjadi keseimbangan. Lingkungan belajar yang menyenangkan serta munculnya emosi sebagai keterlibatan otak dapat menciptakan sebuah interaksi yang baik dalam proses belajar yang akhirnya dapat menimbulkan motivasi yang tinggi pada diri seseorang sehingga secara langsung dapat mempengaruhi proses belajar.

Mind map merupakan salah satu teknik mencatat yang memadukan dan mengembangkan potensi kerja otak yang terdapat di dalam diri seseorang. Tugas dari otak kanan berhubungan dengan irama, kesadaran ruang, imajinasi, melamun, warna, dan kesadaran holistik (Buzan, 2010). Adanya kombinasi warna, simbol, bentuk dan sebagainya pada mind map memudahkan otak dalam menyerap informasi yang diterima. Dengan demikian siswa dapat mengetahui manfaat dari materi yang dipelajarinya, sehingga siswa akan lebih termotivasi untuk belajar.

Penelitian ini bertujuan untuk merancang, mengimplementasikan serta mengetahui peningkatan hasil belajar (kognitif, afektif, psikomotorik) melalui quantum learning dengan teknik mind map.

\section{Metode Penelitian}

Subjek dalam penelitian ini adalah mahasiswa Pendidikan Biologi semester VI FKIP Universitas Tanjungpura tahun akademik 2011/2012. Penelitian ini dilakukan pada akhir bulan Februari sampai awal bulan Mei 2012. Kelas yang digunakan sebanyak satu kelas berjumlah 33 orang, terdiri 
dari 27 mahasiswa perempuan dan 6 orang mahasiswa laki-laki dengan kemampuan yang heterogen. Di dalam ruangan kelas terdapat kursi mahasiswa, kursi dan meja dosen, white board, LCD proyektor, lampu, kipas angin dan jendela kaca serta tirai penutup.

Penelitian yang dilaksanakan ini merupakan Penelitian Tindakan Kelas (PTK) yang dirancang dalam tiga siklus. Masing-masing siklus terdiri dari empat tahap yaitu: tahap perencanaan (planning), tindakan (acting) dan observasi (observing), serta refleksi (reflecting). Sebelum tahapan PTK tersebut dilaksanakan, terdapat tahapan yang dinamakan pra tindakan. Pada tahap ini kegiatan mahasiswa diobservasi dalam kelas, mengadakan wawancara dengan dosen pengampu mata kuliah, serta melihat hasil belajar mahasiswa pada mata kuliah Histologi-Embriologi.

Penelitian tindakan kelas ini dirancang dalam 3 siklus yang masingmasing siklus terdiri dari 1 kali pertemuan. Indikator keberhasilan dalam penelitian ini yaitu untuk hasil belajar kognitif nilai 60 kategori C. Penentuan nilai ini berdasarkan nilai kelulusan untuk tiap mata kuliah. Persentase ketuntasan untuk tiap ranah adalah $75 \%$.

Teknik pengumpulan data digunakan untuk mengumpulkan data meliputi teknik tes dengan soal uraian dan teknik non tes dengan pengamatan atau observasi, wawancara, dan angket.

Validitas diukur menggunakan rumus korelasi product moment. Hasil validasi untuk angket afektif menunjukkan dari 30 soal angket yang ada, 27 soal diantaranya valid dan 3 soal tidak valid. Tiga soal yang tidak valid kemudian direvisi. Hasil uji coba tes KPS menunjukkan bahwa soal KPS yang berjumlah 8 item semuanya dinyatakan valid.

Teknik analisis data meliputi tiga kegiatan yaitu: reduksi data, penyajian data, dan verifikasi data. Reduksi data merupakan kegiatan menyeleksi data sesuai dengan fokus masalah (Sanjaya, 2010). Pada tahap ini data dikelompokkan berdasarkan fokus masalah atau hipotesis. Tujuan dari reduksi data adalah mempertajam, memilih, memfokuskan, dan menyusun data, sehingga kesimpulan akhir dapat dibuat dan diverifikasi (Sunarno, 2011). Penyajian data dapat dilakukan dengan menyajikan tabel, diagram, grafik, tujuannya agar data lebih mudah dibaca. Verifikasi bertujuan untuk menguji validitas dari hasil penarikan kesimpulannya. 


\section{Hasil Penelitian dan Pembahasan}

Tabel 1 Keterlaksanaan Sintaks Per Siklus

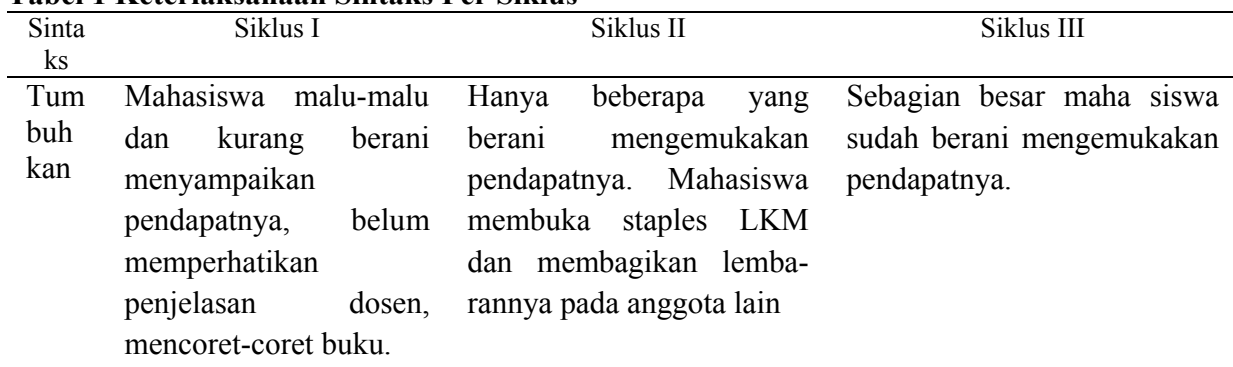

\begin{tabular}{llrlll}
\hline Ala & Diskusi & dilakukan & Beberapa kelompok saja & Mahasiswa sudah bekerja \\
mi & dengan teman sebelah. & yang anggotanya masih sama dan berdiskusi dalam \\
& membuat mind map & diskusi dengan teman kelompoknya \\
& sebelum waktunya, & disebelahnya. Dosen men \\
& dosen hanya men datangi semua kelompok & \\
datangi & kelompok & & \\
tertentu saja & &
\end{tabular}

$\begin{array}{llll}\text { Nam } & \text { Beberapa mahasiswa } & \text { Semua anggota sudah } & \text { Seluruh mahasiswa sudah } \\ \text { ai } & \text { belum terlibat pembu- } & \text { terlibat dalam pembuatan } & \text { terlibat pembuatan mind map } \\ & \text { atan mind map } & \text { mind map }\end{array}$

\begin{tabular}{llll}
\hline Dem & Hanya 1-2 anggota & Semua anggota kelompok & Semua anggota bergantian \\
onst & kelompok yang mem & maju dan bergantian mem & mempresen tasikan mind map \\
rasik & presentasikan mind map & presentasikan mind map & yang telah dibuat \\
an & ke depan kelas. & yang telah dibuat &
\end{tabular}
Ulan Mahasiswa malu-malu Sebagian besar Mahasiswa Sebagian besar Maha siswa gi dan ragu memberikan sudah terlihat lebih per- sudah terlihat lebih percaya pertanyaan, kritik/ ide/ caya diri dalam mengemu- diri dalam mengemukakan saran. Mahasiswa ter kakan pendapatnya. Dosen pendapatnya tentu saja yang aktif. tdk lagi terburu memberi Dosen buru-buru me konfirmasi nyampaikan konfirmasi karena waktu hampir habis

\begin{tabular}{llll}
\hline $\begin{array}{l}\text { Ray } \\
\text { akan }\end{array}$ & $\begin{array}{l}\text { Penilaian mind map ter } \\
\text { baik pada kelompok I }\end{array}$ & $\begin{array}{l}\text { Penilaian mind map } \\
\text { terbaik pada kelompok V V }\end{array}$ & $\begin{array}{l}\text { Peniaian mind map ter-baik } \\
\text { pada kelompok VI }\end{array}$
\end{tabular}


Tabel 2 Tahapan PTK Per Siklus

\begin{tabular}{|c|c|c|c|c|}
\hline $\begin{array}{l}\text { Siklus } \\
\text { ke }\end{array}$ & Perencanaan & $\begin{array}{l}\text { Pelaksanaan/ } \\
\text { Observasi }\end{array}$ & Refleksi & Rekomendasi/Saran \\
\hline $\begin{array}{l}\text { Pra } \\
\text { Tinda } \\
\text { kan }\end{array}$ & & & $\begin{array}{l}\text { Pembelajaran masih ber } \\
\text { sifat teacher centered. } \\
\text { Persentase keaktifan ma } \\
\text { hasiswa hanya } 2,66 \% \text {, } \\
\text { Dosen kurang ber } \\
\text { inovasi dalam hal } \\
\text { model, metode maupun } \\
\text { teknik pembelajaran. }\end{array}$ & $\begin{array}{l}\text { Disarankan menggu } \\
\text { nakan model dan } \\
\text { teknik pembelajaran } \\
\text { selain ceramah agar } \\
\text { membuat mahasiswa } \\
\text { menjadi aktif dan } \\
\text { kreatif }\end{array}$ \\
\hline I & $\begin{array}{l}\text { Berdasar kan } \\
\text { hasil refleksi } \\
\text { dari kegiatan } \\
\text { pra tindakan } \\
\text { bersama } \\
\text { kolaboratorma } \\
\text { ka perangkat } \\
\text { pembelajaran } \\
\text { (SAP, LKM, } \\
\text { Soal Tes, Lem } \\
\text { bar obser } \\
\text { vasi) dibuat } \\
\text { berdasarkan } \\
\text { quantum } \\
\text { learning dan } \\
\text { menggunakan } \\
\text { teknik mind } \\
\text { map. Untuk } \\
\text { mendukung } \\
\text { model } \\
\text { tersebut } \\
\text { diperlukan } \\
\text { alat bantu } \\
\text { seperti video, } \\
\text { gambar, dan } \\
\text { power point. }\end{array}$ & 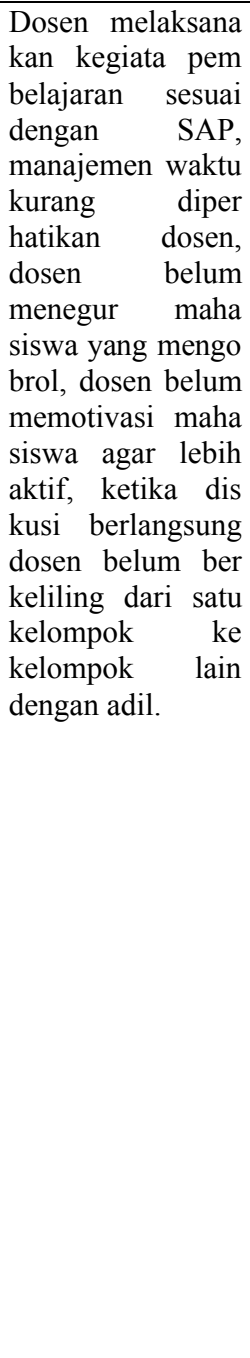 & $\begin{array}{l}\text { Beberapa mahasiswa } \\
\text { datang terlambat, suara } \\
\text { video terlalu kecil, } \\
\text { mahasiswa masih ada } \\
\text { yang mengobrol, maha } \\
\text { siswa telihat malu-malu } \\
\text { ketika dosen meminta } \\
\text { pendapatnya, beberapa } \\
\text { mahasiswa belum mem } \\
\text { perhatikan penjelasan } \\
\text { dosen tapi sibuk men } \\
\text { coret-coret bukunya } \\
\text { menggunakan spidol } \\
\text { yang telah diberikan } \\
\text { dosen. Dosen hanya } \\
\text { mendatangi kelompok } \\
\text { tertentu saja ketika dis } \\
\text { kusi berlangsung, bebe } \\
\text { rapa mahasiswa hanya } \\
\text { berdiskusi dengan } \\
\text { teman disebelahnya, } \\
\text { beberapa kelompok } \\
\text { telah membuat mind } \\
\text { map sebelum waktunya. } \\
\text { Beberapa mahasiswa } \\
\text { belum terlibat dalam } \\
\text { pembuatan mind map, } \\
\text { dan presentasi, maha } \\
\text { siswa yang berani } \\
\text { menyampaikan pen } \\
\text { dapat hanya itu-itu saja. } \\
\text { Dosen buru-buru } \\
\text { menyampaikan materi } \\
\text { karena waktu hamper } \\
\text { habis. mahasiswa masih } \\
\text { menoleh ke kiri dan } \\
\text { kanan saat quis. }\end{array}$ & $\begin{array}{l}\text { Dosen harus meng- } \\
\text { absen mahasiswa. } \\
\text { Memperbesar volume } \\
\text { video dan menegur } \\
\text { ma hasiswa yang } \\
\text { masih mengobrol. } \\
\text { Memberi semangat } \\
\text { pada mahasiswa agar } \\
\text { lebih percaya diri } \\
\text { dalam me ngemukakan } \\
\text { pendapatnya. } \\
\text { Perlengkapan pem } \\
\text { buatan mind map } \\
\text { dibagikan ketika akan } \\
\text { membuat mind map. } \\
\text { Membimbing } \\
\text { mahasiswa dengan adil } \\
\text { dan mengi ngatkan } \\
\text { agar berdiskusi dengan } \\
\text { semua anggota kelom- } \\
\text { pok. Mengarahkan } \\
\text { keterliba tan aktif } \\
\text { dalam pem buatan } \\
\text { mind map. Seluruh } \\
\text { anggota kelom pok } \\
\text { maju dan mempre } \\
\text { sentasikan mind map } \\
\text { yang dibuat. menunjuk } \\
\text { mahasiswa untuk me } \\
\text { nyimpulkan. } \\
\text { Batasan waktu yang } \\
\text { jelas untuk tiap-tiap } \\
\text { tahapan pembelajaran. }\end{array}$ \\
\hline
\end{tabular}




\begin{tabular}{|c|c|c|c|c|}
\hline & & & & $\begin{array}{l}\text { Menegur mahasiswa } \\
\text { yang mencontek dan } \\
\text { memberi sangsi. } \\
\text { Mengecek hasil rang } \\
\text { kuman yang } \\
\text { ditugaskan. }\end{array}$ \\
\hline II & $\begin{array}{l}\text { Berdasarkan } \\
\text { hasil refleksi } \\
\text { dari siklus I } \\
\text { bersama } \\
\text { kolaborator, } \\
\text { maka dosen } \\
\text { perlu memper } \\
\text { hatikan } \\
\text { pembagian } \\
\text { waktu untuk } \\
\text { tiap sintaks } \\
\text { pada quantum } \\
\text { learning } \\
\text { mnggunaka } \\
\text { teknik mind } \\
\text { map. }\end{array}$ & $\begin{array}{l}\text { Dosen telah melak } \\
\text { sanakan kegiatan } \\
\text { pembelajaran } \\
\text { sesuai RPP, dosen } \\
\text { juga telah mem } \\
\text { berikan batasan } \\
\text { waktu yang jelas } \\
\text { untuk tiap sinaks } \\
\text { quantum learning. } \\
\text { Pembagian per } \\
\text { lengkapan mind } \\
\text { map ketika waktu } \\
\text { yang telah diten } \\
\text { tukan.Dosen } \\
\text { berkeliling tiap } \\
\text { kelompok dengan } \\
\text { adil, dosen juga } \\
\text { menegur maha } \\
\text { siswa yang tidak } \\
\text { disiplin. }\end{array}$ & $\begin{array}{l}\text { Beberapa mahasiswa } \\
\text { masih terlihat malu- } \\
\text { malu dalam menyam } \\
\text { paikan ide/pendapatnya. } \\
\text { Sebagian besar maha } \\
\text { siswa telah aktif dalam } \\
\text { pembuatan mind map, } \\
\text { seluruh naggota kelom } \\
\text { pok sudah maju untuk } \\
\text { presentasi, Dosen me- } \\
\text { nyampaikan konfirmasi } \\
\text { materi tidak buru-buru. } \\
\text { Mahasiswa lebih enjoy } \\
\text { dalam mengikuti kegi- } \\
\text { atan pembelajaran. }\end{array}$ & $\begin{array}{l}\text { Dosen member moti- } \\
\text { vasi agar mahasiswa } \\
\text { lebih percaya diri } \\
\text { dalam mengemukakan } \\
\text { pen-dapatnya dengan } \\
\text { mem-beri penguatan. } \\
\text { Batasan waktu yang } \\
\text { jelas diper-lukan } \\
\text { karena pembuatan } \\
\text { mind map menyita } \\
\text { banyak waktu. }\end{array}$ \\
\hline III & $\begin{array}{l}\text { Berdasarkan } \\
\text { hasil refleksi } \\
\text { siklus II ber- } \\
\text { sama kola- } \\
\text { borator maka } \\
\text { perangkat } \\
\text { pembelajaran } \\
\text { dibuat ber- } \\
\text { dasarkan } \\
\text { quantum } \\
\text { learning } \\
\text { dengan teknik } \\
\text { mind map. }\end{array}$ & 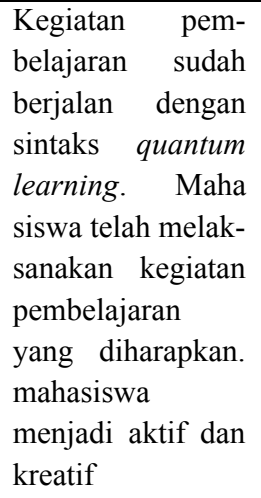 & $\begin{array}{l}\text { Seluruh mahasiswa } \\
\text { sudah terlihat aktif dan } \\
\text { berani dalam mengemu- } \\
\text { kakan ide/pendapatnya. } \\
\text { Kegiatan pembelajaran } \\
\text { telah berjalan sesuai } \\
\text { sintaks yang ada di } \\
\text { SAP. }\end{array}$ & \\
\hline
\end{tabular}

Hasil belajar pada aspek kognitif, afektif, dan psikomotorik disajikan pada tabel 3. 
Tabel 3. Rangkuman Nilai Rata-Rata Aspek Kognitif, Afektif dan Psikomotor Per Siklus

\begin{tabular}{llll}
\hline Aspek & Siklus I & Siklus II & Siklus III \\
\hline Kognitif & 48.06 & 75.50 & 84.63 \\
\hline Afektif & 67.14 & 73.56 & 76.26 \\
\hline Psikomotorik & 63.69 & 75.71 & 78.83 \\
\hline
\end{tabular}

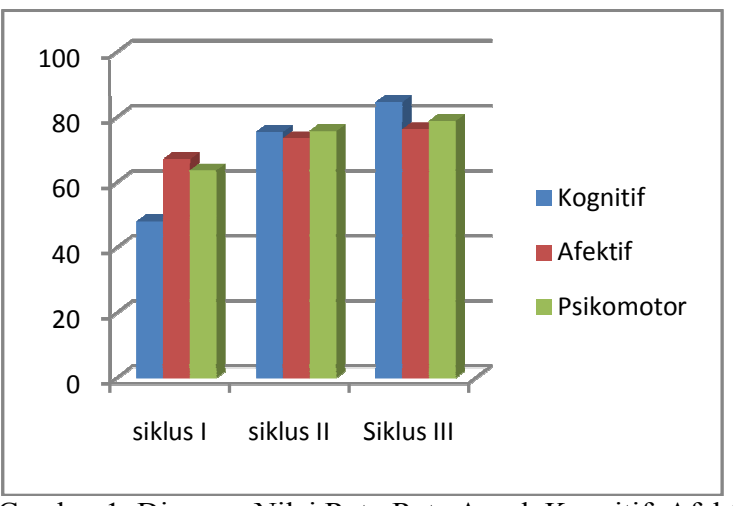

Gambar 1. Diagram Nilai Rata-Rata Aspek Kognitif, Afektif dan Psikomotor.

Berdasarkan Tabel 3 dan Gambar 1, rata-rata nilai pada aspek kognitif, afektif, dan psikomotor mengalami peningkatan pada tiap siklus.

Hasil penilaian pembuatan mind map perkelompok untuk tiap siklus disajikan pada tabel 5 .

Tabel 5. Nilai Pembuatan Mind map Perkelompok Tiap Siklus

\begin{tabular}{cccc}
\hline Kelompok & Siklus I & Siklus II & Siklus III \\
\hline I & 100 & 93.10 & 96.55 \\
\hline II & 89.66 & 89.66 & 96.55 \\
\hline III & 89.66 & 96.55 & 96.55 \\
\hline IV & 75.86 & 89.66 & 89.66 \\
\hline V & 96.55 & 100 & 89.66 \\
\hline VI & 89.66 & 89.66 & 100 \\
\hline
\end{tabular}




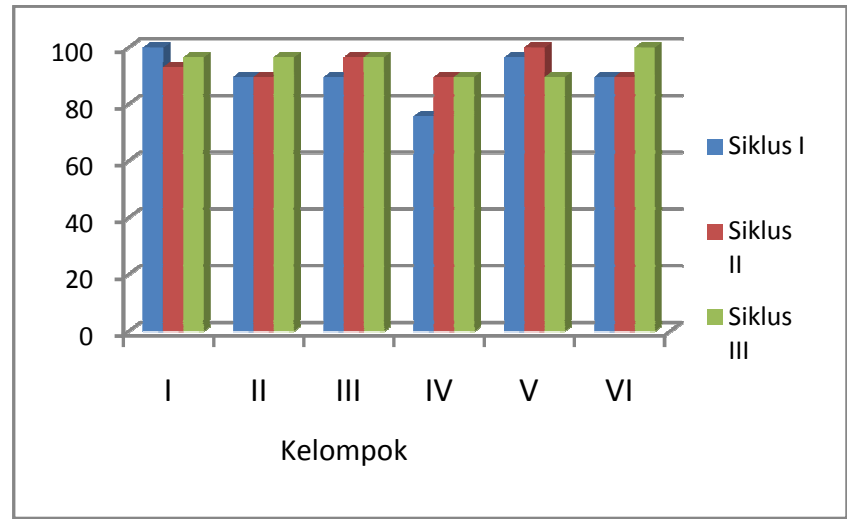

Gambar 3. Diagram Nilai Pembuatan Mind map Per Kelompok Per Siklus

Berdasarkan Tabel 5, nilai tertinggi untuk pembuatan mind map pada siklus I diperoleh oleh kelompok I dengan nilai 100, pada siklus II nilai tertinggi diperoleh oleh kelompok $\mathrm{V}$, dan pada siklus III nilai tertinggi diperoleh kelompok VI.

\section{Pembahasan}

Sanjaya (2010) menjelaskan bahwa terdapat beberapa faktor yang berpengaruh pada proses pembelajaran diantaranya guru, siswa, alat dan media, sarana dan faktor lingkungan. Dalam penelitian menggunakan quantum learning, lingkungan dikondisikan sedemikian rupa agar mahasiswa merasa nyaman dengan lingkungannya.

Sintaks "Tumbuhkan" dalam quantum learning berarti menumbuhkan minat untuk belajar. Menurut Sardiman (2008) minat dapat dibangkitkan dengan cara membangkitkan suatu kebutuhan, menghubungkan dengan pengalaman yang lampau, memberi kesempatan untuk hasil yang lebih baik, dan menggunakan berbagai bentuk, metode dan strategi mengajar. Dalam penelitian ini salah satu kegiatan yang dilakukan dosen untuk membangkitkan minat mahasiswa di awal pembelajaran adalah dengan menanyangkan video tentang proses gametogenesis, fertilisasi dan implantasi yang merupakan materi yang abstrak. Terbukti bahwa model pembelajaran yang menyenangkan akan menumbuhkan minat belajar mahasiswa karena belajar bukan lagi merupakan beban melainkan sesuatu yang menyenangkan. Menurut Suprijanto (2007) ciri-ciri belajar orang dewasa adalah mengharapkan suasana belajar yang menyenangkan dan menantang dan mereka akan belajar sesuatu yang bermanfaat bagi dirinya. Model pembelajaran kuantum sangat cocok diterapkan pada mahasiswa yang merupakan manusia dewasa. 
Sintaks kedua dari kuantum adalah "Alami". Alami adalah kondisi dimana siswa diajak untuk mengalami langsung proses pembelajaran atau mendatangkan pengalaman umum yang dapat dimengerti semua pelajar (A'la, 2010). Pada tahap ini mahasiswa digiring secara langsung untuk mengalami proses pembelajaran dengan memberikan suatu kegiatan yang dapat mengaktifkan pengetahuan yang sudah dimiliki bersama kelompoknya dengan cara mengamati gambar, berdiskusi, mengkomunikasikan data dalam bentuk Tabel, menyimpulkan melalui pemberian LKM. Ketrampilan Proses Sains yang muncul pada sintaks ini adalah mengamati dan mengkomunikasikan data dalam bentuk Tabel. Menurut Piaget dan Vigotsky, anak mengkonstruksi pengetahuan mereka berdasarkan pengalaman. Jadi semakin banyak stimulus yang diberikan dosen kepada mahasiswa, maka akan semakin banyak pengalaman yang mereka dapatkan dan meningkatkan memori ingatan mereka.

Sintaks ketiga adalah "Namai", pada sintaks ini mahasiswa diajak untuk membuat mind map berdasarkan LKM yang telah dikerjakan bersama kelompoknya masing-masing. Mind map adalah bentuk penulisan catatan yang penuh warna dan bersifat visual, yang bisa dikerjakan oleh satu orang atau sebuah tim yang terdiri atas beberapa orang (Buzan, 2005). Pembuatan mind map sesuai dengan teori-teori yang digunakan dalam quantum learning, salah satunya adalah teori otak kanan dan otak kiri. Otak dapat menerima informasi berupa gambar, simbol, citra, musik dan lain lain yang berhubungan dengan fungsi kerja otak kanan. Perpaduan kuantum dengan teknik mind map secara umum dapat meningkatkan hasil belajar. Hal ini sesuai dengan pendapat Naim (2008) yang menyatakan bahwa model pembelajaran kuantum merupakan kiat, petunjuk, strategi, dan seluruh proses belajar yang dapat mempertajam pemahaman dan daya ingat, serta membuat belajar sebagai suatu proses yang menyenangkan dan bermanfaat.

Penggunaan mind map dalam pembelajaran juga merupakan wujud kebermaknaan dalam pembelajaran karena dalam mind map tampak keterkaitan antara konsep-konsep. Belajar bermakna merupakan suatu proses mengaitkan informasi baru pada konsep-konsep relevan yang terdapat dalam struktur kognitif seseorang (Ausubel dalam Dahar, 1989). Kebermaknaan pembelajaran akan membuat kegiatan belajar lebih menarik, lebih bermanfaat dan lebih menantang, sehingga konsep dan prosedur materi yang disampaikan akan lebih mudah dipahami dan lebih tahan lama diingat oleh peserta didik. Mind map dapat menghubungkan ide baru dan unik dengan ide yang sudah ada, sehingga menimbulkan adanya tindakan spesifik yang dilakukan oleh mahasiswa, dengan penggunaan warna dan simbol-simbol 
yang menarik akan menciptakan suatu hasil pemetaan pikiran yang baru dan berbeda.

Sintaks selanjutnya dalam quantum learning adalah "Demonstrasikan". Menurut De Porter (2010), demonstrasikan adalah menyediakan kesempatan bagi para pelajar untuk "menunjukkan bahwa mereka tahu". Hal ini sejalan dengan pendapat A'la (2010). Pada tahap ini dosen memberikan kesempatan mahasiswa untuk mempresentasikan mind map yang telah dibuat perkelompok. Mahasiswa diberi kesempatan untuk mendemonstrasikan/mempresentasikan yang mereka bisa atau yang mereka pahami dari materi yang diberikan.

Ketrampilan proses sains yang muncul pada sintaks ini adalah mengkomunikasikan. Melalui demonstrasi/presentasi ini, mahasiswa akan mampu memahami dan menguasai materi pembelajaran, juga mampu menumbuhkan keberanian, rasa percaya diri, minat serta bakat mahasiswa melalui kreativitas yang mereka munculkan dalan presentasi mind map ini. Bagi dosen, kegiatan ini dapat mengukur pemahaman dan penguasaan mahasiswa terhadap materi.

Sintaks "Ulangi" pada quantum learning, tidak hanya dilakukan dengan ulangan atau menjawab soal-soal. Pada tahap ini, dosen membimbing mahasiswa mengajukan pertanyaan, komentar, serta memberikan ide/kritik/saran terhadap hasil presentasi kelompok yang maju. Baik mahasiswa yang memberikan pertanyaan dan komentar maupun mahasiswa yang presentasi akan lebih mengingat materi yang ditanyakan atau yang dijawab. Dosen juga membimbing mahasiswa untuk menyimpulkan materi yang dipresentasikan, sekali lagi ini merupakan salah satu pengulangan yang dilakukan.

Sintaks terakhir dalam quantum learning adalah "Rayakan". Sintaks rayakan merupakan ekspresi mahasiswa setelah berhasil melakukan sesuatu. Mahasiswa yang mendapat hasil belajar baik tentu akan merasa senang, demikian pula sebaliknya. Karena itu sintaks ini juga berhubungan dengan hasil belajar mahasiswa. Pada penelitian ini dosen memberikan reward berupa bintang pada kelompok dengan mind map dan yel-yel terbaik. Setiap usaha mahasiswa dihargai sekecil apapun itu bentuknya, kesalahan anak dalam belajar dinggap sebagai sesuatu yang manusiawi, karena menurut De Porter bahwa "ketika anak memutuskan untuk belajar, maka sesungguhnya ia sudah keluar dari zona nyamannya, maka hargailah segala usaha yang telah dilakukannya." Penghargaan tidak hanya dengan pemberian nilai, tapi banyak cara yang dapat dilakukan seperti: memberi hadiah, pujian, tepuk tangan, senyuman dan lain-lain. 
Penghargaan yang diberikan akan membangkitksn semangat mahasiswa untuk belajar lebih giat lagi, karena sekali kita mengatakan bahwa "pendapat kamu salah", "tidak seharusnya begitu" maka hal ini akan mematikan minat dan keinginan anak untuk menjelajah pengetahuan yang lebih dalam lagi karena takut divonis "salah" oleh dosen/guru.

\section{Kesimpulan dan Rekomendasi}

Rancangan model pembelajaran kuantum dengan teknik mind map dapat dibuat untuk meningkatkan hasil belajar (kognitif, afektif, psikomotorik mahasiswa Pendidikan Biologi Semester IV FKIP Universitas Tanjungpura Pontianak pada Mata Kuliah Histologi-Embriologi. Model pembelajaran kuantum dengan teknik mind map dapat diterapkan pada mahasiswa Pendidikan Biologi Semester IV FKIP Universitas Tanjungpura Pontianak pada Mata Kuliah Histologi-Embriologi. Quantum learning dengan teknik mind map dapat membangkitkan minat mahasiswa untuk belajar karena pembelajaran menggunakan model ini cukup menyenangkan, selain itu mahasiswa menjadi lebih kreatif karena telah terbiasa membuat mind map. Model pembelajaran kuantum dengan teknik mind map dapat meningkatkan hasil belajar kognitif dengan persentase kelulusan pada siklus I, II, III sebesar $22 \%, 81,25 \%, 96,87 \%$, sedangkan pada ranah afektif rata-rata persiklus adalah $67,14 \%, 73,56 \%$, dan $76,25 \%$, sedangkan pada ranah psikomotor ratarata persiklus adalah $63,69 \%, 75,71 \%$, dan $78,83 \%$.

\section{Daftar Pustaka}

A'la, M. (2010). Quantum Teaching (Buku Pintar dan Praktis). Jogjakarta: DIVA Press

Buzan, T. (2005). Buku Pintar Mind map. Jakarta: Gramedia Pustaka Utama.

Dahar, RW. (1989). Teori-teori Belajar. Jakarta: Erlangga.

De Porter B, Hernacki M. (2001). Quantum learning: Membiasakan Belajar Nyaman dan Menyenangkan (Edisi terjemahan oleh Alwiyah Abdurrahman). Bandung: KAIFA.

De Porter B, Hernacki M and Nourie SS. (2003). Model Kuantum (Edisi terjemahan oleh ry Nilandari). Bandung: KAIFA.

Hinton L, Simpson G, and Smith D. (2008). Increasing Self-efficacy Beliefs in Middle School Students Using Quantum learning Techniques. Journal of Social psychology, Vol 15, Number 130, 353-363. 
Naim, M. (2008). Penerapan metode Quantum Learning dengan Teknik Mind map pada Pembelajaran Fisika. Jurnal Ilmiah Kreatif. Volume VI No.1 Januari 2009.

Purwadi, B. (2003). PISA dan TIMSS 2003. Gambaran Umum Metode Penelitian. Jakarta: Puspendik Depdiknas. (Online). http://nces.ed.gov/timss/result07.asp TIMSS,(10 Oktober 2011)

Sagala, S. (2011). Kemampuan Profesional Guru dan Tenaga Kependidikan. Bandung: Alfabeta.

Sanjaya, W. (2009). Kurikulum dan Pembelajaran. Jakarta: Kencana Prenada Media Group

Sanjaya, W. (2010). Penelitian Tindakan Kelas. Jakarta: Kencana.

Sardiman, A.M. (2009). Interaksi dan Motivasi Belajar Mengajar. Jakarta : PT. Raja Grafindo Persada

Suprijanto. (2007). Pendidikan Orang Dewasa. Jakarta: Bumi Aksara.

Sudarisman, S. Juli (2010). Membangun Karakter Peserta Didik Melalui Pembelajaran Biologi Berbasis Ketrampilan Proses. Prosiding. Disajikan dalam Seminar Nasional VII Pendidikan Biologi, di FKIP UNS.

Sunarno, W. November (2011). Perkembangan Pendidikan dan Pembelajaran Sains Menuju Bangsa yang Berkarakter Kritis dan Kreatif. Makalah. Disajikan dalam Seminar Nasional Pendidikan, di PPS UNS.

Tattersall C, Watts A, Vernon S. (2007). Mind map as a tool in qualitative research. Journal of Nursing Education. Vol: 103, Issue: 26, Page No: 32-33. Diambil pada 2 September 2011 dari http://www.emeraldinsight.com/journals.htm?articleid=880359 